UDC 334.02:339.138

http://doi.org/10.21272/mmi.2019.2-26

JEL Classification: A20, H00, R0O

Aleksandra Kuzior,

D.Sc., Associate Professor, Silesian University of Technology, Poland

Bartosz Sobotka,

Ph.D., Syntea. S.A., Poland

Anastasiia Filipenko

Ph.D., Donetsk Law Institute, Ministry of Internal Affairs of Ukraine, Ukraine

Paulina Kuzior,

Silesian University of Technology, Poland

\title{
MARKETING COMMUNICATIONS OF ADMINISTRATIVE ORGANS OF LOCAL GOVERNANCE AND LOCAL COMMUNITY
}

Abstract. The article deals with questions about the rules of effective, efficient and rational management through the results of marketing communications of administrative units of local self-government. The authors point to the Polish experience in this area with regard to systemic transformation since 1990, based on the decentralization of power and the effective dismissal of social potential, by focusing marketing communications of local governments on activating citizens to take action and ensure citizens' responsibility for the environment. These changes set new tasks for local governments, the proper implementation of which should be based on the implementation of management through the results that can be identified in local government bodies as a process of setting measurable goals for the administration responsible for specific public tasks. implementation of the mechanism of continuous monitoring of these goals, as well as the adaptation mechanism in the context of changes in the internal and external conditions of the organization and informing the public about the results achieved. The results management is based on modern tools used in public finance management, that is, budget execution and management. In order to improve the activities of local self-government bodies, the authors offer lifelong learning in the form of short forms of support (training, courses, seminars) in the process of non-formal learning, taking into account the educational prerequisites for sustainable development. The authors recommend short forms of acquiring new competencies required by the changing environment, challenges related to technological changes and increasing efficiency of market institutions (enterprises), indicating that non-formal education in the field of results management, combining economic, social and ecological aspects is an indispensable element improving the staff of local government administration, aimed at the proper implementation of statutory tasks and competent service of the local community while at the same time rational and effective use of public funds, and thus an essential element of sustainable city management. New management tools implementation combined with the education process can be treated as organisational innovation.

Keywords: lifelong learning, marketing communications, local government administration, management control, management through results, organizational innovation, sustainable city development, task budget, quality of life.

Introduction. An undoubted success of the Polish systemic transformation and economic development was the decentralization of power and the introduction of local governments. The legal foundations of the local government system were included in the constitutional amendment of March 8 , 1990, and specified in the Act of March 8, 1990, on local governments (Ustawa, 1990). The effect of these legislative changes was the restoration of the administrative duality of Polish public authorities. Centralized state power was divided into territorial governmental administration bodies and territorial self-government bodies, respectively dividing the tasks and competencies of particular levels of government (Kallas, 2009). The separation of territorial self-government was tantamount to acknowledging the principle of the multiplicity of public authorities. The monocentric system of power was replaced by a polycentric system (Ferens, 1994). An important qualitative change was the inclusion of residents in communal projects and the introduction of a participatory model of responsibility for the situation in the municipality, city, and province. The decentralization of power enabled the effective liberation of social potential through the

Cite as: Kuzior, A., Sobotka, B., Filipenko, A., \& Kuzior, P. (2019). Marketing Communications of Administrative Organs of Local Governance and Local Community. Marketing and Management of Innovations, 2, 314-325. http://doi.org/10.21272/mmi.2019.2-26 

and Local Community

activities of self-government administration focused on activating citizens. Taking up the responsibility of citizens for their environment has become a factor strengthening regional development, but at the same time, it poses to the local government administration new tasks and challenges related to the skilful use of organizational, financial and media tools to integrate residents around values relevant to shaping civil society. «The task of self-government has also become the promotion of territorial marketing, the aim of which is to create an urban brand that facilitates the acquisition of local government community depending on the adopted strategy - investors, tourists, scientists, consumers, the cultural product of the municipality, etc. local and regional, they gain in importance and popularity on a national scale, and sometimes even gain recognition beyond its borders» (Manka-Szulik, 2015). Making decisions at the lowest level of power, the closest to the citizens is a reasonable solution. However, local governments have not yet worked out the rules of this rationality, all the more so along with technological changes and the increasing efficiency of market institutions (enterprises), local government administration is under constant pressure for improvement and modernization.

Literature review. The research by G. M. Adebo and O. O. Odefadehan (2015) has established a significant link between the program of environmentalizing the city and the sustainable management of ecosystems through marketing communications. The development of Smart Cities is becoming more and more based on knowledge management (KM) (Ardito et al., 2019). This leads to new managerial tasks that reflect the complexity of KM management and the communication processes associated with smart urban projects, as well as the need for knowledge management that comes from both project boundaries and beyond. However, research on the development of intellectual cities from the point of view of managerial and communicative politics is not enough. F. Di Maddaloni and K. Davis (2018) explore how stakeholders from local communities perceive, identify, and classify project managers in large public infrastructure projects. Nevertheless, existing management mechanisms for stakeholders are more reactive than proactive, mainly by offering an instrumental perspective aimed at marketing communications among stakeholders. Thus, in order to increase the efficiency of work, wider inclusiveness of the secondary stakeholders, for example, local communities, is needed to improve work efficiency.

Based on a review of current literature, (Gil-Garcia et al., 2016) defines many aspects of reasonableness and proposes an integrative view that emphasizes how dimension contributes to the understanding and development of intelligent governments. E. Kusakabe (2013) notes the work and impact of public networks on sustainable development at the local level; he examines three examples of current actions for sustainable development in Japanese cities, with particular emphasis on marketing communication networks and the role of local government in this process. According to 0 . Kvilinskyi et al. (2017), is to identify the main social factors that influence the vital activity of society at the present stage of development of territories with an unstable socio-economic situation. Specific tendencies reflecting the state of socio-economic and communicative processes are considered. In the paper by A. Zanella et al. (2014), the authors have shown that all aspects of Smart City's technological infrastructure combined into a single entity, due to marketing communications, will contribute to the successful development of Smart City. The article presents a mathematical model for the search for investment management strategies in information technology and systems related to the concept of Smart City. The model proposed (Lakhno et al., 2018), should be considered as a component of communication of the intellectual system of decisionmaking support in problems analysis of various strategies of mutual financial investment in information technology and Smart City systems. The authors of this paper recommend short forms of acquiring new competencies and marketing communications required by the changing environment. The problems associated with technological change and the increase of the efficiency of market institutions (enterprises) indicate that informal education in the field of results management, combining economic, social and environmental aspects is an integral part of the improvement of the communicative component of the staff of local self-government bodies, aimed at the proper execution of statutory tasks, and therefore as an 

and Local Community

essential element of sustainable city management. The works of A. Lukasiewicz-Kaminska (2015), S. Boonyachut (2016), N. Dalevska et al. (2019), C. Ebdon, and A. Franklin (2004), C. Gurău and L.-P. Dana (2018), Y. Kharazishvili et al. (2019), A Insch and B. Bowdenm (2016), A. Molina et al. (2017), K. Pająk et al. (2016a; 2016b), A. Sodiq et al. (2019), V. Vanolo (2018), S. Villamayor-Tomas and G. Garcia-Lopez (2018), and other also had a particular impact on the development of the marketing communications of administrative organs of local governance and local community in the economic sustainability context.

The aim of this paper is to present selected management mechanisms increasing the efficiency of self-government.

Methodology and research methods. To achieve the goal of this paper, mainly the method of content analysis was used. The source material for the analyses were the existing data, which consists of selected literature on the subject, legal acts, available reports and studies of public institutions in the area of management in local government. For analysis of legal acts, the authors used also the legal and dogmatic research method. At the same time, the method of targeted selection was considered the most adequate in this case. The presented aspects are descriptive and explicative, and the authors' contributions should be treated in a normative way. In addition, partially other scientific research methods for management sciences (Dzwigol \& Dzwigol-Barosz, 2018) were used.

Results. A modern, sustainable self-government community is also an effective administration characterized by the ability and efficiency of action. Unfortunately, despite many statutory changes and on-going improvements, the administration is not keeping up with the changes in the socio-economic reality, and the citizen is still not its client, but still remains a petitioner. In public administration, the most widespread model of management is based on Max Weber's bureaucracy theory as a model of the organizational scheme based on formal and legalized ruling authority oriented to procedures. Such an organization is directed towards, inter alia because it is characterized by such features: a clear division of labour, hierarchy of positions, which creates a chain of command issuing from the top to the bottom of the organization and procedural formalism. The modern approach to managing sustainable city development is based on the resignation of control based on rigid rules and replacing it with shaping mutual relations and focusing on feedback. However, the most important task of the administration should be to focus on meeting the needs and expectations of the client, a member of the local community. Meanwhile, administration burdened with procedures and rigid regulations still differ from the sustainable pattern of a modern office open to the public (Weber, 2012). Nevertheless, Over the last dozen or so years, individual governments in Poland and in the European Union countries successfully implement modern management methods transferred directly from the enterprise sector. Such demands are put forward both by the Organization for Economic Cooperation and Development (OECD) as well as by the European Commission, which is referred to as New Public Management (NPM). The model of public administration, including local government, according to the NPM should be based on such foundations as (Postula \& Perczynski, 2010; Supernat, 2005):

- the administration should focus primarily on achieving results, and only then on processes and activities;

- the administration should achieve results in those areas where it provides specific products and provides services;

- the administration should be oriented towards citizens (consumers) in the context of and real needs that should be known and met;

- the administration should emphasize the way it uses its resources: human, material and financial, and should strive to reduce the costs of providing public services while increasing their quality;

- public administration should develop an organizational culture in the context of flexibility, innovation, problem-solving and entrepreneurial mindsets. 

and Local Community

It follows from the above that the results of activities that are the leader in this concept are very important. That is why the concept of management by results is becoming more and more popular. It is closely related to the task budget and management control. Management by results in local government administration can be defined as the process of setting measurable goals for the administration responsible for specific public tasks with the implementation of a mechanism for continuous monitoring of these goals, and an adaptive mechanism in the context of changing internal and external conditions of the organization and informing the public about the results achieved (Szescilo, 2014). In such a management model, achieving results is more important than formalism resulting from the procedures, and the actions should focus on improving the results, and not just like in process-oriented management - on the reaction to irregularities. A characteristic feature is the emergence of an element of risk as in the enterprise sector, which can be a bonus in the increase in the quality of services provided. On the other hand, the result indicators are to be used to evaluate the actions undertaken and their impact on the inhabitants of a given local government unit, and not to check the compliance of actions with the plan and procedures. The results should be understood as a result of activity, which is a consequence of all anticipated and unpredictable effects of actions aimed at achieving the defined goal. The effects of actions do not always coincide with the defined objectives and therefore these results can be ranked according to a certain scale. In the subject literature, the concept of results is presented in four categories, which are evaluated in an integrated manner:

- Inputs - are the resources (material, financial, HR) owned by the administration sufficient?

- Processes - are the owned resources used effectively?

- Outputs - is the appropriate number and quality of public services provided for which the public administration entity is responsible?

- Outcomes - was there a significant change achieved in the area being the subject of public intervention? (Szescilo, 2014, p. 140).

While two categories (inputs and outputs) are relatively easy to measure using numerical and percentage indicators that are assigned to individual sub-categories, it is difficult to measure processes and results. As mentioned above, the reorientation of administration from procedures to objectives also requires the use of other public finance management tools. To this end, a task budget is used, which is a «public funds management method recognized as a consolidated expenditure plan for public finance sector entities - drawn up over a period longer than one year, in the function of the state (self-government), budget tasks and sub-tasks together with measures determining the degree of implementation of the target» (Postula \& Perczynski, 2010, p. 26). The advantages of the new approach - the task-based budget - are best seen when its features are combined with the classic budget approach used in administration. Table 1 presents the main features of both approaches.

Table 1. A comparison of the characteristics of the traditional budget and the task budget

\begin{tabular}{|l|l|}
\hline \multicolumn{1}{|c|}{ TRADITIONAL BUDGET } & \multicolumn{1}{|c|}{ TASK BUDGET } \\
\hline \multicolumn{1}{|c|}{ 1 } & \multicolumn{1}{|c|}{$\mathbf{1}$} \\
\hline Expense tool & Management tool \\
\hline $\begin{array}{l}\text { Difficult connection with government goals and } \\
\text { control of the effectiveness of task } \\
\text { implementation }\end{array}$ & $\begin{array}{l}\text { It conduces clarifying the objectives of public administration, } \\
\text { including self-government, and monitoring the effectiveness } \\
\text { of their implementation }\end{array}$ \\
\hline $\begin{array}{l}\text { Budget expenditure not integrated with another } \\
\text { public sector expenditure }\end{array}$ & A global approach to public sector expenditure \\
\hline Difficult hierarchisation of expenditure & $\begin{array}{l}\text { Hierarchy of expenditures and instruments according to } \\
\text { significance for social and economic development }\end{array}$ \\
\hline Static approach - budget year & $\begin{array}{l}\text { Long-term approach. Annual budget resulting from multi- } \\
\text { annual budget planning }\end{array}$ \\
\hline
\end{tabular}


A. Kuzior, B. Sobotka, A. Filipenko, P. Kuzior. Marketing Communications of Administrative Organs of Local Governance and Local Community

\begin{tabular}{|l|l|}
\hline \multicolumn{1}{|c|}{ Continue Table 1.} \\
\hline $\begin{array}{l}\text { Lack of knowledge about the effectiveness of } \\
\text { expenses incurred }\end{array}$ & Measuring the ratio of effort to results (effectiveness) \\
\hline Budget classification requires specialized knowledge & Clear information about budget expenditures \\
\hline $\begin{array}{l}\text { It directs the discussion of the legislative power on } \\
\text { individual expenditure items }\end{array}$ & $\begin{array}{l}\text { Enables substantive discussion during the debates of } \\
\text { the legislative body }\end{array}$ \\
\hline The holder administers the funds & $\begin{array}{l}\text { The holder manages the funds and is responsible for } \\
\text { the implementation of the program }\end{array}$ \\
\hline
\end{tabular}

Source: compiled by the authors on the basis of (Podstawka et al., 2007).

As can be seen from the above comparison, using the task-oriented budget in addition to focusing on specific results being the consequences of undertaken actions, this tool is transparent for the citizen who should actively participate in community-building processes in the context of sustainable development. Speaking about the development of Poland, it is worth noting that GDP growth over the past ten years is characterized by relative stability up to 500 USD billion (Fig. 1). From the point of view of management through results, it is important to specify the goals that should be:

1. Essential - should reflect important socio-economic needs, important for society and fulfilling its needs.

2. Precise and specific - defined in a simple, understandable and clear way, ensuring unambiguous interpretation.

3. Consistent - complementary within the structure of the performance budget, not replicating in individual sentences.

4. Measurable - the degree of their implementation should be measurable by means of specific measures.

5. Defined in time - oriented towards the future, although in relation to the current state.

6. Realistic - aimed at improving the results, although also taking into account the level of risk of their implementation (Kargol-Wasiluk \& Wojewodko, 2016, pp. 162-163).

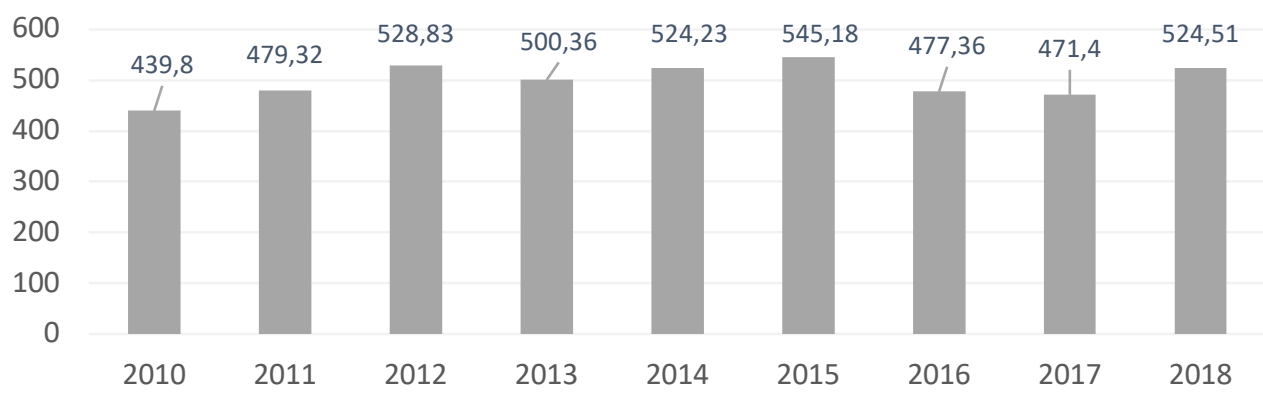

Figure 1. Poland GDP, USD billion

Source: developed by authors based on (World Bank, 2019)

Measures must enable measuring the effectiveness and efficiency of tasks, subtasks and actions. For this purpose, the base value and the target value are determined. The base value is not defined for completely new public tasks (Kargol-Wasiluk \& Wojewodko, 2016, p. 163). After determining the objectives relevant to the interest of citizens and indicating adequate measures, a plan of budget expenditures can be constructed with reference to individual objectives, tasks, subtasks and activities, i.e. to prepare a task budget which is a tool supporting management efficiency and effectiveness. The history of the 

and Local Community

development of the approach to public finance management based on the task-based budget in Poland is relatively short since it dates back to 2006 when the first works related to the implementation of this idea began (Postula \& Perczynski, 2008). Task budgeting, however, has earlier traditions dating back to the 1940s, when the implementation of this type of budget innovation began in the USA (Kargol-Wasiluk \& Wojewodko, 2016). This model, although relatively easy to describe, is more difficult to use in practice. In the initial phase of implementing the task-based budget, barriers were identified that were the result of long-established procedures. W. Misiag included to the main barriers to the implementation of the task budget in the central (national) administration the following:

- «the reluctance of the administration to implement new methods and to undergo additional control procedures,

- incompatibility of legal norms specifying the standards for performing public tasks with actual possibilities (financial, staff and organizational),

- the weakness of the non-governmental institutions' sector,

- maladjustment of administration structures for management by objectives,

- non-compliance with the Public Finance Act for activity budgeting,

- the level of human resources administration,

- the inability to manage large projects (programs),

- lack of coordination of tasks of individual ministries in the implementation of task budgeting,

- gaps in public statistics, hindering the proper selection of performance indicators,

- the excessive number of existing government strategies and programs,

- treating the full absorption of funds from the EU budget as an end in itself» (Misiag, 2013).

W. Misiag also indicates that local government units more efficiently assimilate a new form of budgeting than the central administration, eliminating the emerging barriers and although the level of these changes varies (Misiag, 2013), it would undoubtedly be possible to give many examples of good practices in this area. However, it should be emphasized once again that a task budget is an important tool for managing results and thus an important tool for sustainable development. The last element related to the implementation of results-based management is the management control system in local government units. In Poland, the Act of 27 August 2009 on public finances imposed on managers of public finance sector entities, including territorial self-government, the obligation to provide managed management units in managed units, which is to support the implementation of objectives and tasks in the context of compliance with law, increasing efficiency, increasing savings and ensuring timeliness (Ustawa z 27 sierpnia 2009,2009$)$. It is worth noting that annually there is a reduction in the state budget deficit of the country's GDP (Fig. 2, Fig. 3).

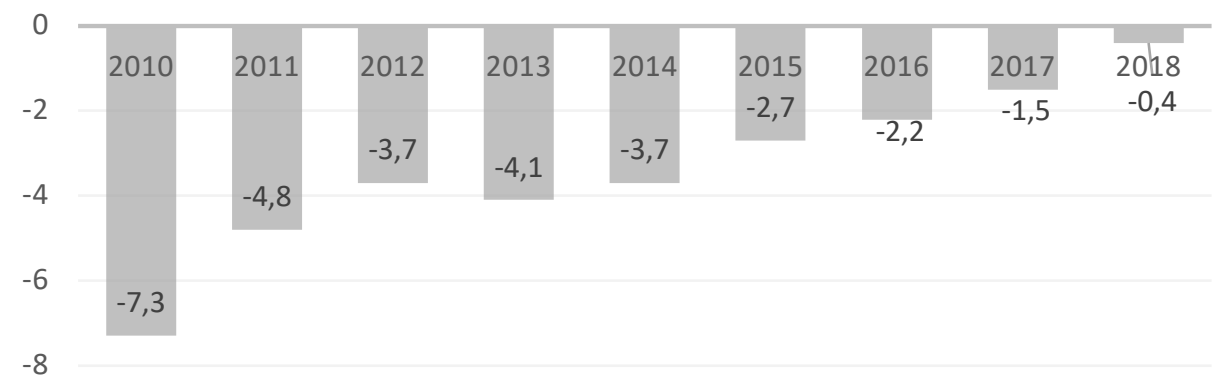

Figure 2. Poland Government Budget, \%

Source: developed by authors based on (Central Statistical Office of Poland, 2019). 
A. Kuzior, B. Sobotka, A. Filipenko, P. Kuzior. Marketing Communications of Administrative Organs of Local Governance and Local Community

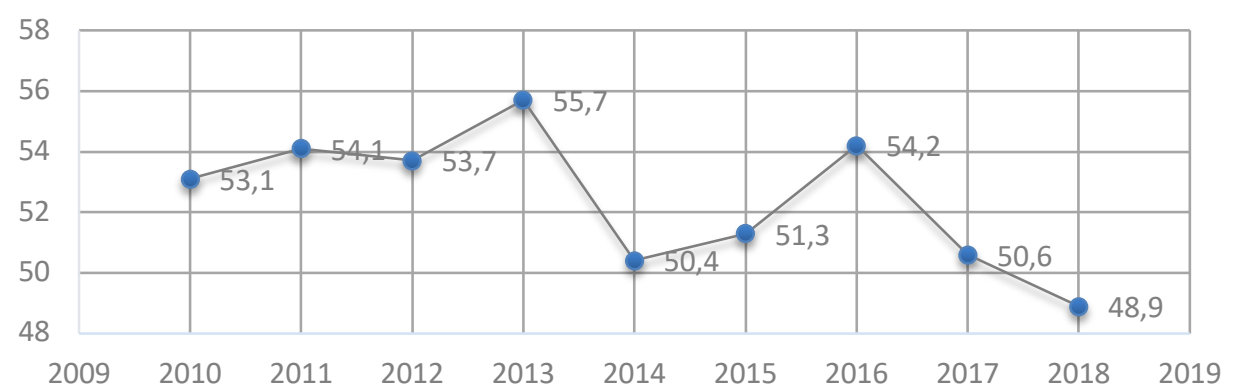

Figure 3. Poland Government Debt to GDP, \%

Source: developed by authors based on (Central Statistical Office of Poland, 2019).

The reduction in the share of the public debt of Poland in GDP occurs against the background of increasing revenues of local government budgets and a slight reduction in spending (fig. 4, fig. 5).

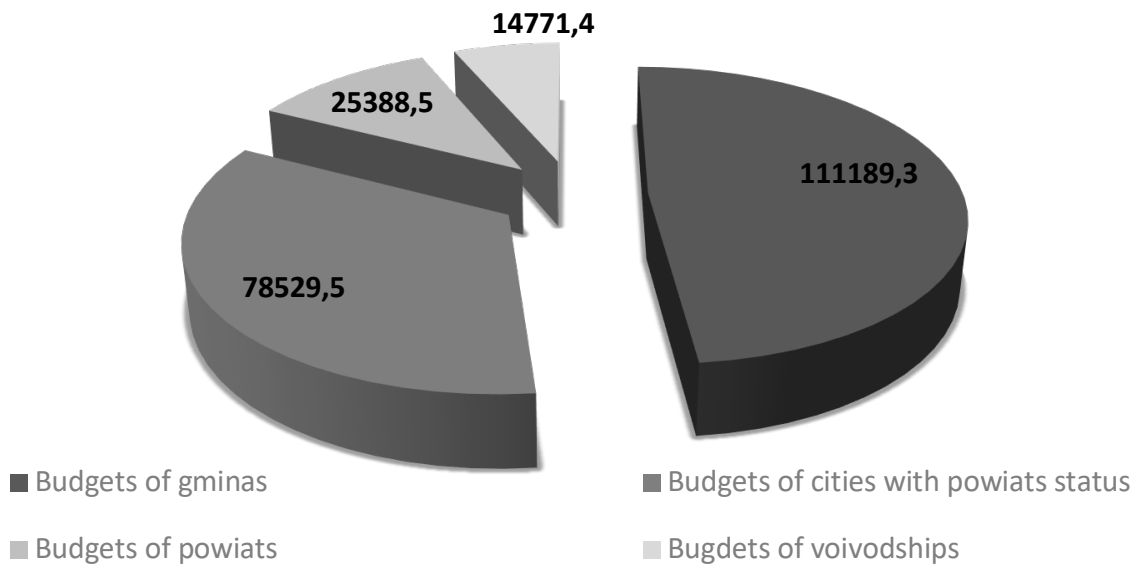

Figure 4. Local Government Revenue 2018, mIn. PLN

Source: developed by authors based on (Statistical, 2018; 2019). 


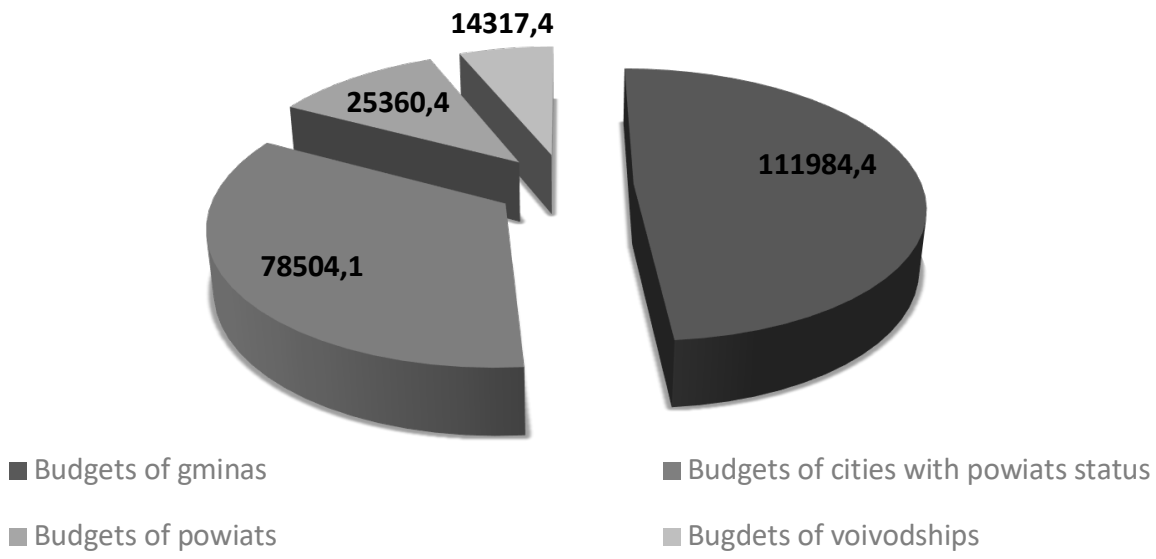

Figure 5. Local Government Expenditure 2018, mIn. PLN

Source: Source: developed by authors based on (Statistical, 2018; 2019).

Pursuant to the statutory definition, the purpose of management control is also to increase efficiency, and hence to verify the ratio of inputs to achieved results, which means that its subject is all resources that the local government has at its disposal, in other words: human, financial, property, archival and processes that affect the smooth functioning of the unit. Considering the fact that such control is connected with the entire management process has a much wider scope than internal control, which is - to simplify it - aimed at searching for irregularities, and not improving them. Management control is aimed at improving the quality of services and public tasks provided to its client (citizen). Facilitating the implementation of the management control system are decentralization of management, controlling, budgeting, including primarily (described above) task budgets. However, it is not easy to implement these tools, as it requires proper preparation. It is important to identify the type of organizational structure of the unit, to eliminate autocratic management, to apply delegation of authority. This is possible with the introduction of a decentralized structure, where specific centres of responsibility are responsible for the implementation of the tasks assigned to them. The appropriately tailored network of information channels is of significant importance in the decentralized organizational structure. It is also important that the system is subjected to permanent assessment of its effectiveness, improvement of functionality and usefulness in preventing irregularities (Dzwigol, 2012). As mentioned, the task-based budget is an important tool supporting the implementation of management control in local government units.

Conclusions. The above-outlined proposals for changing the management model of the local government community implemented in Poland and other European Union countries in the context of the post-industrial knowledge-based economy paradigm require also, or rather, above all, redefining the approach to the qualifications of local government officials. Formal education, and therefore the diploma of a higher education institution, on the one hand, is slowly ceasing to be a pass to the civil service corps, and on the other hand, a guarantee of maintaining employment. The new approach requires high adaptability of qualifications and competencies of the administration employees, the more so that changes in the method and tools of management often cause the resistance of employees who are not prepared both competently and mentally for introduced changes. One of the possibilities of improving qualifications and expanding competences there are short forms of education in line with the Lifelong learning policy, which is a panacea for technological and organizational changes of the market and non-market institutions 

and Local Community

(Chang, 2013). The Lifelong learning idea is not new at all, because more than a century ago, decisionmakers in the countries of Western democracy have pointed out that the foundation for the development of a modern state is education aimed at educating people of all ages. (The Final Report, 1919). Young people should have the opportunity to be educated in formal education, and adults and older citizens should be able to use non-formal education as part of the concept of lifelong learning (courses, pieces of training, workshops). Dynamic technological changes and global social changes have made matters of life-long learning addressed by UNESCO, the UN Agenda for Education, Science and Culture. In 1968, the French intellectual René Maheu, the then director general of UNESCO, in his report pointed out that the concept of lifelong education is a response to the needs related to the development of civilization. The famous Delors report also highlights the importance of Lifelong learning as an educational concept that is key to the gates of the 21st century (Sobierajski, 2016). According to the report, education should be based on four pillars:

- learn in order to know - acquire the tools to understand the world;

- learn in order to act - acquire the ability to influence the surrounding world, the environment;

- learn in order to live together - acquiring the ability to cooperate with others and participate in activities with other people;

- learn in order to be - to create opportunities for development for every human being, so that they can develop their intelligence, sensitivity, sense of aesthetics, responsibility and critical thinking.

«Education should transmit massively and effectively more and more knowledge and skills that evolve, adequate to cognitive civilization because they are the basis for the competences of tomorrow. (...) Education is in a way obliged to provide a map of a complex and ever-restless world and a compass that makes it possible to navigate it» (Report dla UNESCO, 1998). The modern educational process should be introduced by modern local government officials who, despite the fact that they have basic qualifications gained through formal training, but the dynamics of the modern world and the development of modern technologies mean that the competences of administrative staff should be constantly expanded. This is necessary for the establishment of effective marketing communications, competent customer service, a citizen of the city with specific needs and requirements. Meeting these needs is one of the priorities of local self-government bodies, which fit into the goals set by the idea of sustainable development. The main task of this idea is to improve the quality of life of the inhabitants. The quality of life, as the central category of sustainable development, focuses not only on the anthropocentric approach to meeting the needs of man, but also draws attention to the fact that the quality of life of people and entire societies depends on the health of ecosystems, the health of nature that surrounds us and is its «home», a place where its existential needs are realized (Kuzior, 2014). Therefore, the self-government administration, performing tasks aimed at ensuring the high quality of life of its citizens, must take into account an important condition for the protection of the natural environment in which a person lives. Therefore, in order to set goals, it is necessary to find the one that concerns the protection and improvement of the quality of the natural environment. Therefore, the budget for efficiency should include this important component of effective and results-oriented management. Although the quality of life affects mainly the health of ecosystems, other factors are equally important, such as: satisfaction of basic needs (food, hygiene, housing), effective law, knowledge transfer and innovative technologies, access to information, access to information culture and education, decision-making models on the basis of participation, ensuring basic human rights and freedoms. The high quality of life of a particular person also determines personal security, which includes, inter alia, ICT security, environmental, health, economics, energy and social security (Kuzior, 2014). In these areas, local self-government bodies are required to carry out their activities independently or in cooperation with the departments of the state administration. The scope and diversity of tasks faced by local authorities, as well as the dynamics of current technical and technological changes, making it necessary for continuous professional development that is possible within the framework of informal 

and Local Community

education in short forms of support at courses, pieces of training and seminars. The aforementioned learning process can be provided within the framework of a market qualification determined in accordance with the Integrated Qualifications Framework in Poland, compatible with the European Qualifications Framework. Such an approach can ensure the high quality of the activities being undertaken, as the learning process ends with formal verification and certification. It is governed by the Law of 22 December 2015 on a comprehensive system of qualifications [Journal of the Laws of 2017, Article 986] (Note from December 22, 2015). The authors recommend these forms of acquiring new competencies in the context of improving the marketing communications required by the changing environment, pointing out that informal education in the management of results, combining economic, social and environmental aspects, is an important element of improving local self-government staffing focused on proper execution of statutory tasks and competent servicing of the local community in the rational and efficient use of public funds. Prospects for further research in this direction are the simulation of a multivariate marketing communications development for local government and local community staff.

Authors Contributions: conceptualization and supervision, A. K., B. S., A. F., \& P. K.; methodology, A. K., B. S., A. F., \& P. K.; investigation and writing, A. K., B. S., A. F., \& P. K.; formal analysis and visualization, A. K., B. S., A. F., \& P. K.; review and editing, A. K., B. S., A. F., \& P. K.

\section{References}

Adebo, G.M., \& Odefadehan, O.O. (2015). Analysis of City Greening Approach to Sustainable Ecosystem Management in Ondo State. Environmental Management and Sustainable Development, 4(1) 149-163. http://dx.doi.org/10.5296/emsd.v4i1.7047

Ardito, L., Ferraris, A., Petruzzelli, A.M., Bresciani, S., \& Del Giudice, M. (2019). The role of universities in the knowledge management of smart city projects. Technological Forecasting and Social Change, 142, 312-321. https://doi.org/10.1016/.techfore.2018.07.030

Boonyachut, S. (2016). Sustainability of community's entrepreneurship: case of floating market at Ladmayom. Entrepreneurship and Sustainability Issues, 4(2), 211-219. https://doi.org/10.9770/jesi.2016.4.2(8)

Central Statistical Office of Poland (2019). Retrieved from https://stat.gov.pl/en/

Chang, H.-J. (2013). 23 rzeczy ktorych nie mowią Ci o kapitalizmie [23 Things They Don't Tell You About Capitalism]. Warszawa: Wydawnictwo Krytyki Politycznej [in Polish].

Di Maddaloni, F., \& Davis, K. (2018). Project Manager's Perception of the Local Communities' Stakeholder in Megaprojects. An Empirical Investigation in the UK. International Journal of Project Management, 36(3), 542-565. https://doi.org/10.1016/.jijproman.2017.11.003

Dalevska, N., Khobta, V., Kwilinski, A., \& Kravchenko, S. (2019). A model for estimating social and economic indicators of sustainable development. Entrepreneurship and Sustainability Issues, 6(4), 1839-1860. https://doi.org/10.9770/jesi.2019.6.4(21)

Dzwigol, H. (2012). Mechanizmy kontroli dotyczące operacji finansowych i gospodarczych. [Control Mechanisms for financial and economic operations]. Zeszyty Naukowe Politechniki Sląskiej, Organizacja i Zarządzanie, 60, $61-82$ [in Polish].

Dzwigol, H., \& Dzwigol-Barosz, M. (2018). Scientific Research Methodology in Management Sciences. Financial and Credit Activity: Problems of Theory and Practice, 2(25), 424-437. https://doi.org/10.18371/fcaptp.v2i25.136508

Ebdon, C. \& Franklin, A. (2004). Searching for a Role for Citizens in the Budget Process. Public Budgeting and Finance, 24 32-49. https://doi.org/10.1111/j.0275-1100.2004.02401002.x

Ferens, A. (1994). Transformacja systemu wladzy lokalnej w Polsce. Proba identyfikacji zasadniczych tendencji [Transformation of the local authority system in Poland. An attempt to identify basic tendencies]. In A. Antoszewski (Ed.), Ewolucja polskiego systemu politycznego po 1989 roku w swietle komparatystycznej teorii polityki The evolution of the Polish political system after 1989 in the light of the comparative theory of politics]. Wroclaw: Wydawnictwo Uniwersytetu Wroclawskiego [in Polish].

Gil-Garcia, J.R., Zhang, J., \& Puron-Cid, G. (2016). Conceptualizing Smartness in Government: An Integrative and MultiDimensional View. Government Information Quarterly, 33(3), 524-534. https://doi.org/10.1016/j.giq.2016.03.002

Gurău, C., \& Dana, L.-P. (2018). Environmentally-Driven Community Entrepreneurship: Mapping the Link between Natura Environment, Local Community and Entrepreneurship. Technological Forecasting and Social Change, 129, 221-231. https://doi.org/10.1016/.techfore.2017.11.023

Insch, A., \& Bowdenm, B. (2016). Possibilities and limits of brand repositioning for a second-ranked city: The case of Brisbane, Australia's "New World City", 1979-2013. Cities, 56, 47-54. https://doi.org/10.1016/j.cities.2016.03.003

Kallas, M. (2009). Historia ustroju Polski [The History of Political System in Poland]. Warszawa: Wydawnictwo Naukowe PWN. 
Kargol-Wasiluk, A., Wojewodko, E. (2016). Budzet zadaniowy jako narzędzie poprawy jakosci rządzenia (na przykladzie podlaskiego urzędu wojewodzkiego) [Task Budget as a Tool to Improve the Quality of Governance (on the example of the Podlasie Voivodship Office)].. Optimum, Studia Ekonomiczne, 2(86), 155-177 [in Polish].

Kharazishvili, Y., Grishnova, O., \& Kaminska, B. (2019). Standards of living in Ukraine, Georgia, and Poland: identification and strategic planning. Virtual Economics, 2(2), 7-36. https://doi.org/10.34021/ve.2019.02.02(1)

Kuzior, A. (2014). Aksjologia zrownowazonego rozwoju [Axiology of Sustainable Development]. Banska Bystrzyca: Belianum. Kusakabe, E. (2013). Advancing Sustainable Development At the Local Level: The Case of Machizukuri in Japanese Cities. Progress in Planning, 80, 1-65. https://doi.org/10.1016/j.progress.2012.06.001

Kvilinskyi, O., Mieshkov, A., \& Bondaryeva, I. (2017). Investigation of the Social Factors of Development of Society in the Territories with Transforming Environment. Research Papers in Economics and Finance, 2(2), 13-19. https://doi.org/10.18559/ref.2017.2.2

Lakhno, V., Malyukov, V., Bochulia, T., Hipters, Z., Kwilinski, A., \& Tomashevska, O. (2018). Model of Managing of the Procedure of Mutual Financial Investing in Information Technologies and Smart City Systems. International Journal of Civil Engineering and Technology, 9(8), 1802-1812. Retrieved from http://www.iaeme.com/MasterAdmin/UploadFolder/ IJCIET_09_08_181/IJCIET_09_08_181.pdf

Lukasiewicz-Kaminska, A. (2015). Sustainable City Marketing: a Modern Management Model. Zeszyty Naukowe Uniwersytetu Szczecinskiego. Problemy Zarządzania, Finansow I Marketingu, 867(40), 33-42. https://doi.org/10.18276/pzfm.2015.40-03

Manka-Szulik, M. (2015). Samorząd terytorialny jako czynnik rozwoju lokalnego i regionalnego [Local government as a factor of local and regional development]. Zeszyty Naukowe Politechniki Sląskiej. Organizacja i Zarządzanie, 79, 165-177. Retrieved from http://www.woiz.pols.pl/znwoiz/z79/Ma\%f1ka_Szulik_\%20pop.pdf [in Polish]

Misiag, W. (2013). Siedem lat wdrazania budzetu zadaniowego - refleksje i prognozy [Seven Years of Implementing the TaskBudget - Reflections and Forecasts]. In K. Marchewka-Bartkowiak, Z. Szpringer (Eds.), Budzet zadaniowy [Task Budget] (pp. 85122). Warszawa: Biuro Analiz Sejmowych Kancelarii Sejmu [in Polish].

Molina, A., Fernández, A.C., Gomez, M., \& Aranda, E. (2017). Differences in the city branding of European capitals based on online vs. offline sources of information. Tourism Management, 58, 28-39. https://doi.org/10.1016/.tourman.2016.10.005

Pajak, K., Dahlke, P., \& Kvilinskyi, O. (2016a). Determinanty rozwoju regionalnego - wspolczesne odniesienie [Determinants of the regional development - contemporary reference]. Roczniki Ekonomiczne Kujawsko-Pomorskiej Szkoly Wyzszej w Bydgoszczy, 9, 109-122.

Pajak, K., Kaminska, B., \& Kvilinskyi, O. (2016b). Modern Trends of Financial Sector Development under the Virtual Regionalization Conditions. Financial and Credit Activity: Problems of Theory and Practice, 2(21), 204-217. https://doi.org/10.18371/fcaptp.v2i21.91052

Podstawka, M., Dynowska, J., Goralski, P. \& Rudowicz, E. (2007). Przygotowanie administracji rządowej do sporządzania zadaniowego planu wydatkow na rok 2008. Materialy szkoleniowe [Preparing the Government Administration to Prepare a TaskBased Expenditure Plan for 2008. Training Materials], Warszawa: Kancelaria Prezesa Rady Ministrow [in Polish].

Postula, M., Perczynski, P. (Eds.) (2010). Budzet zadaniowy w administracji publicznej [Task Budget in Public Administration]. Warsaw: Ministry of Finance [in Polish].

Sobierajski, T. (2016). Uczenie sie przez cale zycie jako wyzwanie i szansa. Polityka Senioralna 2 [Lifelong Learning as a Challenge and Opportunity. Senior Policy 2]. Retrieved form https://polityka.zaczyn.org/polityka-senioralna/polityka-senioralna-nr-2/ [in Polish].

Raport dla UNESCO Międzynarodowej Komisji do spraw Edukacji dla XXI wieku pod przewodnictwem Jacques'a Delorsa „Edukacja: jest w niej ukryty skarb” [Report for UNESCO of the International Commission on Education for the 21st Century, Chaired by Jacques Delors «Education: there is a Hidden Treasure in It»]. (1998). Warszawa: Stowarzyszenie Oswiatowcow Polskich.

Sodiq, A., Baloch, A.A.B., Khan, S.A., Sezer, N., Mahmoud, S., Jama, M., \& Abdelaal, A. (2019). Towards Modern Sustainable Cities: Review of Sustainability Principles and Trends. Journal of Cleaner Production, 227, 972-1001. https://doi.org/10.1016/.j.jclepro.2019.04.106

Statistical Yearbook of the Regions - Poland 2018. (2019). Retrieved from https://stat.gov.pl/en/topics/statisticalyearbooks/statistical-yearbooks/statistical-yearbook-of-the-regions-poland-2018,4,13.html

Supernat, J. (2005). Administracja publiczna w swietle koncepcji New Public Management [Public Administration in the Light of the New Public Management Concept]. Wroclaw: Uniwersytet Wroclawski [in Polish].

Szescilo, D. (2014). Administracja i zarzadzanie publiczne. Nauka o wspolczesnej administracji Administration and Public Management. Learning about Modern Administration]. Warszawa: Stowarzyszenie Absolwentow Wydzialu Prawa i Administracji Uniwersytetu Warszawskiego [in Polish].

The Final Report. (1919). British Ministry of Reconstruction. London: Adult Education Committee. HMSO.

Ustawa z dnia 8 marca 1990 r. o samorządzie terytorialnym (Dz. U. z 1990 r. Nr 16. Poz. 95) [The Act of 8 March 1990. Local Government (Journal of Laws of 1990. No. 16, Item 95)]. (1990). Retrieved from http://dziennikustaw.gov.pl/DU/1990/s/16/95/1 [in Polish].

Ustawa z dnia 27 sierpnia 2009 r. o finansach publicznych z poz. zm. (Dz. U. z 2011 r. Nr 185, poz. 1092, Nr 201, poz. 1183) [The Act of 27 August 2009. Public Finance. (Journal of Laws of 2011. No. 185, Item 1092. No. 201, Item 1183)]. (2011). Retrieved from http://dziennikustaw.gov.pl/DU/2009/s/157/1240/1 [in Polish]. 
A. Kuzior, B. Sobotka, A. Filipenko, P. Kuzior. Marketing Communications of Administrative Organs of Local Governance and Local Community

Ustawa z dnia 22 grudnia 2015 r. o Zintegrowanym Systemie Kwalifikacji (Dz. U. z 2017 r. poz. 986) [Act of 22 December 2015 The Integrated Qualification System (Journal of Laws of 2017, Item 986). (2017). Retrieved from http://dziennikustaw.gov.pl/du/2016/64 [in Polish].

Vanolo, V. (2018). Politicising city branding: Some comments on Andrea Lucarelli's 'Place branding as urban policy'. Cities, 80, 67-69. https://doi.org/10.1016/j.cities.2018.06.004

Villamayor-Tomas, S. \& Garcia-Lopez, G. (2018). Social Movements as Key Actors in Governing the Commons: Evidence from Community-Based Resource Management Cases across the World. Global Environmental Change, 53, 114-126. https://doi.org/10.1016/j.gloenvcha.2018.09.005

Weber, E. (2012). Nowoczesne podejscie do zarzadzania zasobami ludzkimi w samorzadzie [Modern Approach to Human Resource Management in Local Government]. Zeszyty Naukowe Politechniki Sląskiej, Organizacja i Zarządzanie, 63a, 291-300 [in Polish].

World Bank. (2019). Retrieved from https://www.worldbank.org/

Zanella, A., Bui, N., Castellani, A., Vangelista, L., \& Zorzi, M. (2014). Internet of Things for Smart Cities. IEEE Internet of Things journal, 1(1), 22-32. https://doi.org/10.1109/JIOT.2014.2306328

A. Кужьор, D.Sc., Сілезька політехніка (Польща),

Б. Соботка, Ph.D., компанія Syntea. S.A. (Польща);

A. Філіпенко, к.Ю.н., Донецький юридичний інститут МВС України (Україна),

П. Кужьор, Сілезька політехніка (Польща).

Маркетингові комунікації адміністративних органів місцевого самоврядування та місцевих громад

У статті розглядаються питання щодо правила ефективного, результативного та раціонального управління за допомогою результатів маркетингових комунікацій адміністративних одиниць місцевого самоврядування. Автори вказують на польський досвід у цій сфрері щодо системної трансфоормації з 1990 року, що базується на децентралізації влади та ефективному звільненні соціального потенціалу, зосереджуючи маркетингові комунікації органів місцевого самоврядування на активізації громадян для вжиття заходів та забезпечення відповідальності громадян для навколишнього середовища. Ці зміни встановлюють нові завдання для органів місцевого самоврядування, належне виконання яких має грунтуватися на впровадженні управління через результати, які можуть бути визначені в органах місцевого самоврядування як процес встановлення вимірних иілей для адміністрації, відповідальної за конкретні суспільні завдання, впровадження механізму постійного моніторингу цих цілей, а також механізму адаптації в контексті змін внутрішніх і зовнішніх умов організації та інфоормування громадськості про досягнуті результати. Управління результатами базується на сучасних інструментах, що використовуються в управлінні державними фрінансами, тобто у виконанні та управлінні бюджетом. З метою вдосконалення діяльності органів місцевого самоврядування авторами запропоновано впровадити навчання протягом усього життя у формі коротких фоорм підтримки (навчання, курси, семінари) у процесі неформального навчання з урахуванням освітніх передумов для сталого навчання. розвитку. Автори рекомендують використовувати короткі фрорми набуття нових компетенцій, що вимагаються мінливим середовищем та проблемами, що пов'язані 3 технологічними змінами та підвищенням ефеективності ринкових інститутів (підприємств). у статті доведено, що неформальна освіта у сфері управління результатами, що поєднує економічні, соціальні та екологічні аспекти, є невід'ємним елементом вдосконалення персоналу органіє місцевого самоврядування, спрямованого на належне виконання статутних завдань і компетентне обслуговування місцевої громади при одночасному раціональному та ефеективному використанні державних коштів. Нові засоби реалізації в поєднанні з навчальним процесом можна розглядати як організаційні інновації.

Ключові слова: безперервне навчання, маркетингові комунікації, адміністрація місцевого самоврядування, управлінський контроль, управління через результати, організаційні інновації, стале місто, бюджет завдання, якість життя.

Manuscript received: 27.03.2019.

(C) The authors 2019. This article is published with open access at Sumy State University. 